УДК 633.11:633.5

(C) 2015

\author{
Попов С. І., доктор сільськогосподарських наук, \\ Цехмейструк М. Г., кандидат сільськогосподарських наук, \\ Манько К. М., кандидат сільськогосподарських наук, \\ Усов О. С., аспірант \\ (науковий керівник - доктор сільськогосподарських наук С. І. Попов) \\ Інститут рослинництва ім. В. Я. Юр'єва НААН України

\section{ВИКОРИСТАННЯ ОСНОВНИХ ЕЛЕМЕНТІВ ЖИВЛЕННЯ СУЧАСНИМИ СОРТАМИ ПШЕНИЦІ ТВЕРДОЇ ЯРОЇ ЗАЛЕЖНО ВІД ПОПЕРЕДНИКА І ФОНУ ЖИВЛЕННЯ}

Рецензент - доктор сільськогосподарських наук А. О. Рожков

У статті висвітлено дворічні (2013-2014 рр.) дані 3 визначення сортових особливостей споживання основних елементів живлення за різних попередників та фонів мінерального живлення в умовах східної частини Лісостепу Украӥни. Встановлено, щчо найбільше поживних речовин на формування $1 \mathrm{~m}$ зерна затрачає сорт Новачія. Так, у середньому витрати поживних речовин на фоні без добрив становили 28 кг азоту, 10 кг фосфору та 14 кг калію, а на фоні післядї- $30 \mathrm{~m} / 2 а$ гною зі внесенням $N_{60} P_{60} K_{60}-36$ кг азоту, 14 кг фосфору та 15 кг калію.

Ключові слова: пшениця тверда яра, сорт, попередник, фон живлення, поживні речовини.

Постановка проблеми. Вибір режиму живлення для пшениці твердої ярої має вирішальне значення у формуванні врожаю зерна та його якості. Пшениця тверда яра $є$ чутливою культурою до добрив та добре використовує їх післядію, оскільки має слаборозвинену кореневу систему. Досліджень з визначення оптимальної дози мінеральних добрив у різних грунтовокліматичних умовах проведено достатньо, проте встановлені оптимальні значення потребують періодичного оновлення у зв'язку зі зміною родючості грунтів, створення селекціонерами нових високопродуктивних інтенсивних сортів та значним підвищенням вартості мінеральних добрив, що в поєднанні зі зміною умов зволоження робить ці дослідження актуальними.

Аналіз основних досліджень і публікацій, у яких започатковано розв'язання проблеми. У науковій літературі досить велика кількість даних про винос основних елементів живлення пшеницею ярою. За літературними даними на формування врожайності 1 т/га зерна рослини пшениці твердої ярої виносять із грунту 35-45 кг азоту, 8-12 кг фосфору і 17-27 кг калію. Така розбіжність у широких межах пов'язана з рівнем родючості грунтів, умовами навколишньо- го середовища, добривами та врожайністю культури $[1,2]$. В умовах європейської частини Росії на формування $1 \mathrm{~T} /$ га зерна пшениця тверда яра витрачає 48-61 кг азоту, 16 кг фосфору та 26-30 кг калію [3]. В умовах північного Казахстану пшениця тверда яра виносить 50-43 кг азоту, 9 кг фосфору та 24-34 кг калію [4]. За даними вітчизняних науковців для формування врожаю зерна 1 т/га та відповідної кількості побічної продукції рослини пшениці ярої виносять із грунту у середньому 30 кг азоту, 17 кг фосфору та 20 кг калію [5-7]. Також під час вибору режиму живлення потрібно враховувати і вид пшениці, бо пшениця тверда, у порівнянні 3 м'якою, виносить значно більше азоту. Так, на формування 1 т/га зерна твердій пшениці потрібно 35 кг азоту, м'яка ж пшениця використовує 22-25 кг азоту, проте пшениця м'яка більше потребує фосфору на формування продукції [7-9].

Метою досліджень було визначити сортові особливості споживання сучасними сортами пшениці твердої ярої основних елементів живлення за різних попередників в умовах східної частини Лісостепу України.

Завданням досліджень було визначити норми витрат поживних речовин, коефіцієнти використання та окупність добрив зерном сортів пшениці твердої ярої для потреби на формування врожаю зерна залежно від попередника.

Умови і методика проведення досліджень. Польові дослідження проводили впродовж 2013-2014 pp. у стаціонарній паро-зернопросапній сівозміні лабораторії рослинництва та сортовивчення Інституту рослинництва ім. В. Я. Юр'єва НААН за чергування культур чорний пар - пшениця озима - буряк цукровий - пшениця яра - горох на зерно - пшениця озима - кукурудза на зерно $0,5+$ соя $0,5-$ пшениця яра - соняшник.

Досліди закладали за багатофакторними 


\section{СІЛЬСЬКЕ ГОСПОДАРСТВО. РОСЛИННИЦТВО}

схемами методом розщеплених ділянок з урахуванням усіх вимог методики польового досліду $[10,11]$. Ділянками першого порядку були такі попередники: кукурудза на зерно, соя, буряки цукрові; другого порядку - фони мінерального живлення без добрив (контроль), сівозмінний фон, який формується під впливом природної родючості грунту і чергування культур та післядія 30 т/га гною зі внесенням під зяблеву оранку складного мінерального добрива - нітроамофоски. Ділянками третього порядку були сорти пшениці твердої ярої: Спадщина, Ізольда, Жізель, Династія, Новація.

Лабораторні дослідження 3 визначення основних елементів живлення проводили в лабораторії інструментальних методів досліджень ННЦ «Інститут грунтознавства та агрохімії ім. О. Н. Соколовського» НААН згідно з вимогами проведення досліджень в агрохімії $[12,13]$.

Технологія вирощування пшениці твердої ярої була загальноприйнята для східної частини Лісостепу України, окрім досліджуваних елементів. Грунт дослідної ділянки - чорнозем типовий глибокий слабовилугований на пилувато-суглинковому лесі, який характеризується зернисто-грудкуватою структурою, добрими фізико-механічними властивостями. Вміст гумусу (за Тюріним) становить 5,8\%; pH - 5,8; гідролітична кислотність - 3,29 мг-екв на 100 г грунту.

Результати досліджень. У проведених нами дослідженнях протягом 2013-2014 рр. забезпеченість грунту такими основними поживними елементами, як азот, фосфор і калій у доступній для рослин формі залежала від попередників та фонів живлення. Так, після попередника кукурудза на зерно на фоні без добрив (контроль) запас гідролізованого азоту в середньому сягав 129 мг/кг грунту (дуже високий вміст), рухомого фосфору - 90 мг/кг грунту (середній вміст) та рухомого калію - 132 мг/кг грунту (високий вміст), після попередника соя - 125 мг/кг (дуже високий), 85 мг/кГ (середній) та 126 мг/кг (високий), після попередника буряки цукрові - 113 мг/кг (дуже високий), 88 мг/кг (середній) та 119 мг/кг (підвищений) відповідно до елементів.

У випадку застосування мінеральних добрив у дозі $\mathrm{N}_{60} \mathrm{P}_{60} \mathrm{~K}_{60}$ запас поживних речовин у грунті підвищувався залежно від попередників. Після попередника кукурудза на зерно запас гідролізованого азоту в середньому сягав 149 мг/кг грунту (дуже високий вміст), рухомого фосфору - 165 мг/кг грунту (високий вміст) та рухомого калію - 177 мг/кг грунту (високий вміст), після попередника соя 142 мг/кг (дуже високий), 157 мг/кг (високий) та
163 мг/кг (високий), після попередника буряки цукрові - 129 мг/кг (дуже високий), 149 мг/кг (підвищений) та 160 мг/кг (високий) відповідно до елементів живлення.

Дослідженнями встановлено, що на формування 1 т зерна сорту пшениці твердої ярої після попередника кукурудза на зерно в середньому витрачали 24 кг N, 9 кг $\mathrm{P}_{2} \mathrm{O}_{5}$ та 12 кг $\mathrm{K}_{2} \mathrm{O}$, після попередника соя витрачали 29 кг $\mathrm{N}, 8$ кг $\mathrm{P}_{2} \mathrm{O}_{5}, 11$ кг $\mathrm{K}_{2} \mathrm{O}$, а після попередника буряки цукрові в середньому - 26 кг азоту $\mathrm{N}, 9$ кг $\mathrm{P}_{2} \mathrm{O}_{5}$ та 12 кг $\mathrm{K}_{2} \mathrm{O}$. I3 внесенням мінеральних добрив на фоні післядії 30 т/га гною витрати поживних речовин підвищувалися та становили після попередника кукурудза на зерно в середньому по сортах 31 кг $\mathrm{N}$, 12 кг $\mathrm{P}_{2} \mathrm{O}_{5}$ та 14 кг $\mathrm{K}_{2} \mathrm{O}$, після попередника соя витрачали 32 кг N, 14 кг $\mathrm{P}_{2} \mathrm{O}_{5}, 13$ кг $\mathrm{K}_{2} \mathrm{O}$, а після попередника буряки цукрові - 34 кг N, 13 кг $\mathrm{P}_{2} \mathrm{O}_{5}$ та 13 кг $\mathrm{K}_{2} \mathrm{O}$.

Серед сортів найбільше поживних речовин витрачав сорт Новація. Так, у середньому по попередниках витрати поживних речовин на фоні без добрив становили 28 кг N, 10 кг $\mathrm{P}_{2} \mathrm{O}_{5}$ та 14 кг $\mathrm{K}_{2} \mathrm{O}$, а на фоні післядії 30 т/га гною зі внесенням $\mathrm{N}_{60} \mathrm{P}_{60} \mathrm{~K}_{60}-36$ кг N, 14 кг $\mathrm{P}_{2} \mathrm{O}_{5}$ та 15 кг $\mathrm{K}_{2} \mathrm{O}$. Затрати поживних речовин на фоні без застосування добрив для сорту Спадщина становили 27 кг, 9 кг та 11 кг, для сорту Ізольда -27 кг, 8 кг та 12 кг, для сорту Жізель - 26 кг, 9 кг та 11 кг та для сорту Династія - 25 кг, 9 кг, 11 кг відповідно до елементів живлення $\mathrm{N}, \mathrm{P}_{2} \mathrm{O}_{5}$ та $\mathrm{K}_{2} \mathrm{O}$. На фоні iз застосуванням мінеральних добрив затрати для сорту Спадщина становили 31 кг, 13 кг та 12 кг, для сорту Ізольда - 30 кг, 11 кг та 13 кг, для сорту Жізель - 33 кг, 14 кг та 14 кг та для сорту Династія - 31 кг, 13 кг, 14 кг відповідно до елементів живлення $\mathrm{N}, \mathrm{P}_{2} \mathrm{O}_{5}$ та $\mathrm{K}_{2} \mathrm{O}$.

$\mathrm{Y}$ середньому по попередниках сорти пшениці твердої ярої засвоювали поживні речовини 3 грунту на рівні $\mathrm{N}-26 \%, \mathrm{P}_{2} \mathrm{O}_{5}-10 \%, \mathrm{~K}_{2} \mathrm{O}-10 \%$. Найкраще засвоєння поживних речовин 3 грунту було після попередника соя: на фоні без добрив коефіцієнт використання становив у середньому $\mathrm{N}-26 \%, \mathrm{P}_{2} \mathrm{O}_{5}-11 \%, \mathrm{~K}_{2} \mathrm{O}-10 \%$, а на фоні внесення добрив використання поживних речовин збільшувалося і в середньому по сортах становило $\mathrm{N}-30 \%, \mathrm{P}_{2} \mathrm{O}_{5}-12 \%, \mathrm{~K}_{2} \mathrm{O}-11 \%$. Найменше використання поживних речовин 3 грунту було після попередника кукурудза на зерно на фоні без добрив $\mathrm{N}-17 \%, \mathrm{P}_{2} \mathrm{O}_{5}-9 \%, \mathrm{~K}_{2} \mathrm{O}-9 \%$, а на удобреному: $\mathrm{N}-29 \%, \mathrm{P}_{2} \mathrm{O}_{5}-10 \%, \mathrm{~K}_{2} \mathrm{O}-11 \%$.

Коефіцієнти використання азоту для сортів Династія та Новація в середньому встановлені на рівні $21 \%$, а для сортів Спадщина, Ізольда та Жізель - 22 \% на фоні без застосування добрив. 


\section{СІЛЬСЬКЕ ГОСПОДАРСТВО. РОСЛИННИЦТВО}

У випадку застосування добрив коефіцієнти використання азоту підвищувалися та становили для сортів Спадщина та Династія $28 \%$, Ізольда 29 \%, Жізель - 31 \% та Новація - 33 \%. Коефіцієнт використання фосфору на фоні без застосування добрив для сорту Ізольда становив 9\%, Спадщина, Династія та Новація - 10 \%, а для сорту Жізель - $11 \%$. У сорту Жізель коефіцієнт використання в разі застосування мінеральних добрив у середньому по попередниках не змінювався та становив $11 \%$, такі ж коефіцієнти використання фосфору були і у сортів Спадщина, Династія та Новація. У сорту Ізольда коефіцієнт використання становив $10 \%$.

Найменші коефіцієнти використання калію на фоні без добрив встановлені у сортів Спадщина, Жізель та Династія - 9 \%. Для сортів Ізольда та Новація коефіцієнт використання калію становив 10 \%. У сорту Спадщина коефіцієнт використання калію під час внесення мінеральних добрив не змінювався та становив $9 \%$. У сорту Новація встановлено найвищий коефіцієнт використання калію - $12 \%$. Для сортів Ізольда та Жізель цей показник становив $11 \%$, а для сорту Династія $10 \%$.

Під час визначення окупності добрив урожаєм зерна встановлено, що найбільшу окупність 1 кг д. p. NPK зерном у середньому по сортах відмічено після попередника кукурудза на зерно 3,39 кг. Після попередника соя спостерігалась

\section{БІБЛІОГРАФІЯ}

1. Удобрение основных сельськохозяйственных культур / [Годунов И. Б., Дорохов А. П., Яремина Г. Г. и др.] // Научные основы и рекомендации по применению удобрений в ЦЧЗ. Воронеж, 1976. - С. 54-66.

2. Панников В. Д. Научные основы и рекомендации по применению удобрений в ЦентральноЧерноземной зоне / В. Д. Панников, И. С. Шатилов, В. Г. Минеев. - Воронеж, 1976. - 152 с.

3. Кумаков B. A. Физиология яровой пшеницы / В. А. Кумаков. - М. : Колос, 1980. - 207 с.

4. Яровая пшеница : колл. монография / [Бараев А. И., Бакаев Н. М., Веденеева М. Л. и др. ; под ред. А. И. Бараева]. - М. : Колос, 1978. - 429 с.

5. Рослинництво : підручник [для студ. аграр. спец.] / [Влох В. Г., Дубовський С. В., Кияк Г. С., Онищук Д. М.]. - К. : Вища школа, 2005. - 381 с. - (Львівськ. держ. аграр. ун-т).

6. Рослинництво : підручник [для бакалаврів агр. спец.] / [Каленська С. М., Шевчук О. Я., Дмитришак М. Я., Козяр О. М., Демидась Г. І.]. К., 2005. - 502 с. - (Нац. аграр. ун-т).

7. Рожков А. О. Яра пшениця у Східному Лі- найменша окупність 1 кг д. р. NPK зерном - 1,61 кг. Після попередника буряки цукрові окупність 1 кг д. p. NPK зерном становила 2,08 кг.

Серед сортів найбільшу окупність 1 кг д. p. NPK зерном відмічено у сорту Ізольда після попередника кукурудза на зерно - 3,78 кг, що у порівнянні із середньою окупністю по сортах - вище на 0,39 кг. Після попередників соя та буряки цукрові найвищу окупність 1 кг д. р. NPK зерном встановлено у сорту Новація - 2,51 кг та 2,85 кг відповідно до попередників. У сорту Жізель після попередників кукурудза на зерно та соя була найменша окупність 1 кг д. p. NPK зерном - 3,16 кг та 0,74 кг відповідно до попередників. Після попередника буряки цукрові найменшу окупність встановлено у сорту Спадщина - 1,41 кг.

Висновок. Проведеними дослідженнями встановлено потреби сучасних сортів пшениці твердої ярої в поживних речовинах в умовах східної частини Лісостепу України для розрахунку доз добрив під запланований урожай. Встановлено, що сорти витрачають на формування 1 т зерна таку кількість поживних речовин: сорт Спадщина - 22-32 кг N, 9-14 кг $\mathrm{P}_{2} \mathrm{O}_{5}$ та 10-12 кг $\mathrm{K}_{2} \mathrm{O}$; Ізольда - 23-31 кг N, 7-12 кг $\mathrm{P}_{2} \mathrm{O}_{5}$ та 12-13 кг $\mathrm{K}_{2} \mathrm{O}$; Жізель - 26-37 кг N, 9-15 кг $\mathrm{P}_{2} \mathrm{O}_{5}$ та 1014 кг $\mathrm{K}_{2} \mathrm{O}$; Династія - 24-33 кг N, 8-13 кг $\mathrm{P}_{2} \mathrm{O}_{5}$, 10-14 кг $\mathrm{K}_{2} \mathrm{O}$; Новація - 26-39 кг N, 9-14 кг $\mathrm{P}_{2} \mathrm{O}_{5}$ та 11-14 кг $\mathrm{K}_{2} \mathrm{O}$.

состепу України : монографія / А. О. Рожков ; [за ред. М. А. Бобро]. - Х. : Майдан, 2010. - 232 с.

8. Якість зерна сортів ярої пшениці селекції IP ім. В. Я. Юр'єва у зв’язку з азотним, фосфорним та калійним живленням грунту / [Попов С. I., Панченко І. А., Полєско Ю. А., Юрченко П. Х.] // Вісник ХДАУ. - Серія «Грунтознавство, агрохімія, землеробство, лісове господарство». - Х., 2000. - T. 2. - C. 118-124.

9. Залежність урожаю та якості зерна ярої твердої пшениці від вмісту в грунті поживних речовин / [Попов С. І., Панченко І. А., Полєско Ю. А., Лучной В. В.] // Селекція і насінництво. - Х. : IP ім. В. Я. Юр'єва, 2000. - Вип. 84. - С. 84-92.

10. Методические рекомендации по изучению сортовой агротехники в селекцентрах / [подготовили П. П. Литун, В. М. Костромитин, Л. В. Бондаренко]. - М. : ВАСХНИЛ, 1984. - 32 с.

11. Доспехов Б. А. Методика полевого опыта (с основами статистической обработки результатов исследований) / Б. А. Доспехов. - [5-е изд., доп. и перераб.]. - М. : Агропромиздат, 1985. $351 \mathrm{c}$. 


\section{СІЛЬСЬКЕ ГОСПОДАРСТВО. РОСЛИННИЦТВО}

12. Методи аналізів грунтів і рослин : навч. посіб. / [Булигін С. Ю., Балюк С. А., Міхновська А. Д. та ін.]. - Х., 1999. - 157 с.
13. Михайлов H. Н. Определение потребности растений в удобрениях / Н. Н. Михайлов, В. П. Книпер. - М. : Колос, 1971. - 256 с. 